\title{
Quantitative relationships between phytoplankton, bacteria and heterotrophic microflagellates in shelf waters
}

\author{
E. A. S. Linley, R. C. Newell and M. I. Lucas \\ Institute for Marine Environmental Research, Prospect Place, The Hoe, Plymouth PL1 3DH, United Kingdom
}

\begin{abstract}
Estimates of the numbers and biomass of bacteria as a function of depth in coastal and upwelling waters off the western approaches to the English Channel and in the southern Benguela upwelling region off the Cape Peninsula, South Africa, show that the numbers of bacteria are correlated with the standing stocks of phytoplankton as assessed by chlorophyll a concentration. Standing stocks of heterotrophic microflagellates in the size range 3 to $10 \mu \mathrm{m}$, amount to some $16.9 \%$ on average, of bacterial standing stocks $\left(\mathrm{mg} \mathrm{C} \mathrm{m}^{-3}\right)$ estimated by direct microscopy. Calculations of carbon flow through the microheterotrophic consumer community suggest that approximately 20 to $60 \%$ of primary production, possibly representing the dissolved components leaching out of, and lost from phytoplankton cells during zooplankton grazing, enters the microbial food chain. Much of this appears to be dissipated by bacteria, with some 5.2 to $8.1 \%$ of the photoassimilated carbon being incorporated into bacterial carbon production. At least $66 \%$ of this is exploited by the heterotrophic microflagellates leaving a maximum of $34 \%$ of bacterial production for the larger bactivorous suspension feeders.
\end{abstract}

\section{INTRODUCTION}

Although it is generally recognized that the numbers and biomass of bacteria in the sea are correlated with regions of high primary productivity, and that the heterotrophic flagellates may be significant consumers of marine bacteria (Pomeroy and Johannes, 1968; Sieburth et al., 1978; Haas and Webb, 1979; Hollibaugh et al., 1980), there have been comparatively few attempts to quantify the relationship between the standing stocks of bacteria and phytoplankton, or between the bacteria and heterotrophic microflagellates. Ferguson and Palumbo (1979) have reported that the number of bacteria in neritic waters south of Long Island, USA, is positively correlated with chlorophyll and ammonium concentrations, whilst Fuhrman et al. (1980) have shown that bacterioplankton growth rate is more influenced by the standing stock of phytoplankton than by primary production, suggesting that bacterial growth may be stimulated by leakage of dissolved organic matter from aging, disrupted and incompletely digested phytoplankton cells. Sorokin (1971a, b, 1975 , 1977), and Sorokin and Mikheev (1979) in a series of pioneer investigations, studied the partitioning of car- bon amongst the standing stocks of heterotrophic microplankton and made some estimates of energy flow through the microplankton compared with the larger zooplankton.

Such estimates have, in the past, been hampered not only by a scarcity of detailed information on the standing stocks of heterotrophic microplankton, including bacteria, flagellates and ciliates, in marine systems but above all by a lack of data on production and consumption requirements of key consumer organisms. Recently, a good deal of information has become available on bacterial production rates (Meyer-Reil, 1977; Sorokin, 1978; Delattre et al., 1979; Hagström et al., 1979; Sieburth, 1979; Karl, 1980; Fuhrman and Azam, 1980; Newell and Christian, 1981; Newell, 1983) and on the carbon conversion efficiency of heterogeneous populations of marine bacteria on natural detrital sources (Linley et al., 1981; Lucas et al., 1981; Newell et al., 1981; Robertson et al., 1982) as well as on the consumption requirements of a variety of marine flagellates (Fenchel 1982a, b, c, d) and ciliates (Fenchel, 1980; Burkill, 1982). It is thus possible to make some realistic estimates of carbon flow through the microheterotrophic consumer organisms in a variety of 
pelagic systems, provided that simultaneous measurements are made of each of the components of the standing stocks in the water column.

The following work was therefore undertaken to measure the standing stocks and primary production of phytoplankton, as well as the standing stocks of bacteria, flagellates and ciliates in several different sea areas. We then used the information which has recently become available for production and carbon requirements of the bacteria and flagellates to estimate carbon flow through the microheterotrophic community as a whole. The results in general conform with previous estimates (see Williams, 1981) and suggest that approximately 20 to $60 \%$ of the carbon fixed by primary production enters the microbial food chain and that at least $66 \%$ of bacterial production is removed by the heterotrophic microflagellates in coastal waters.

\section{MATERIALS AND METHODS}

\section{Sampling sites}

The data summarized below were obtained on 3 different cruises. The first was the Nimbus G cruise of the Sea Fisheries Institute, Cape Town, between 6. 11. and 14.11. 78 from the edge of the kelp beds on the west coast of the Cape Peninsula, South Africa, to the edge of the continental shelf in the southern Benguela upwelling region (Lat. $34^{\circ} \mathrm{S}$; Long. $18^{\circ} \mathrm{E}$; Fig. 1 b). During this cruise, samples were taken from 3 depths at 4 stations. The second cruise was aboard R. V. 'Sarsia' (Marine Biological Assoiciation, U.K.) to the central Celtic Sea WSW of the Scilly Isles (Lat. $49^{\circ} 40^{\prime} \mathrm{N}_{\text {; }}$ Long. $07^{\circ} 10^{\circ} \mathrm{W}$; see Station P34, Fig. 1a) on 13.8.80. The final cruise was aboard the R.V. 'Frederick Russell'
(Marine Biological Association, U.K.) between 22. 7. and 2.8.81 to 3 main stations in the western approaches to the English Channel. The first station (M) was representative of mixed waters at Lat. $49^{\circ} 19^{\prime} \mathrm{N}_{;} \quad 03^{\circ} 15^{\prime} \mathrm{W}$, the second station $(\mathrm{F})$ was at the frontal region at Lat. $49^{\circ} 19^{\prime} \mathrm{N} ; 04^{\circ} 34^{\prime} \mathrm{W}$ and finally the third station (E5) was representative of deeper stratified waters at $49^{\circ} 04^{\prime} \mathrm{N} ; 06^{\circ} 37^{\prime} \mathrm{W}$. The position of each of these stations is shown in Fig. 1a (see also Holligan et al., 1983). In addition, an inshore station (A1 in Fig. 1a) was sampled at 7 depths on 6. 4., 13. 4., 27.4 and 4.5 .82 to establish temporal variability in the standing stocks of microheterotrophic organisms.

\section{Sampling procedure}

$$
\text { Pumped samples }
$$

Samples were taken over a vertical profile of $60 \mathrm{~m}$ depth at the English Channel stations (M, F, E5) and Celtic sea station (P34) with a submersible pump (Flygt Pumps Ltd., Model B2051). The intake hose of $5 \mathrm{~cm}$ internal diameter was raised at a rate of $2 \mathrm{~m} \mathrm{~min}^{-1}$ from 60 to $2 \mathrm{~m}$ and the average flow rate was $160 \mathrm{l}$ $\mathrm{min}^{-1}$. Water over the depth ranges 60 to $48 \mathrm{~m}, 48$ to $36 \mathrm{~m}, 36$ to $24 \mathrm{~m}, 24$ to $12 \mathrm{~m}$ and 12 to $2 \mathrm{~m}$ was then allowed to flow into a series of 5 leached $20 \mathrm{l}$ plastic vessels from which samples for subsequent analyses were taken immediately.

\section{N.I.O. bottles}

A series of up to $101.51 \mathrm{NIO}$ bottles was also used to collect discrete water samples over the same depth at which the pumped samples were taken in the English
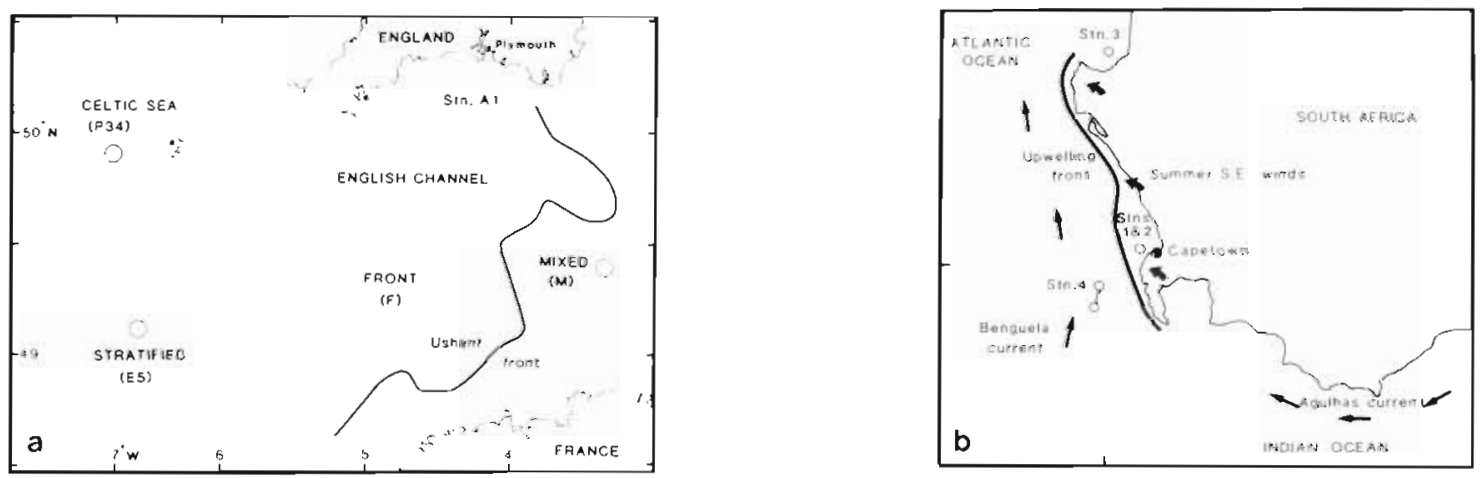

Fig. 1. (a) Sampling stations in nearshore region (Station A1), inixed (Station M) frontal (Station F), stratified waters (Station E5) off the western approaches to the English Channel, and the Celtic Sea (Station P34) sampling site near the Scilly Isles. (b) Sampling sites in the Southern Benguela upwelling region off the western Cape Peninsula, South Africa, sampled during the Nimbus G cruise (Station 1, sampled 11. 11. 78; Station 2, 12.11 78; Station 3, 13.11. 78; Station 4, 14. 11. 78). The approximate position of the upwelling frontal system is shown in each area by a line 
Channel (M, F, E5). The minimum distance between bottles was $2 \mathrm{~m}$, but in general bottle samples were taken at intervals of 6 to $10 \mathrm{~m}$ with somewhat closer spacing over the chlorophyll maximum and thermocline layers. The bottles were subsequently placed on racks on the deck and the water immediately sampled for analysis. Samples were taken at station A1 with $1.51 \mathrm{NIO}$ bottles at $5 \mathrm{~m}$ intervals from the surface to $20 \mathrm{~m}$ depth and at 35 and $50 \mathrm{~m}$. Benguela samples (Nimbus G cruise) were taken at the surface, at $50 \%$ of surface light (corresponding with a depth of 10 to $25 \mathrm{~m}$ ) and at $10 \%$ (corresponding with 20 to $50 \mathrm{~m}$ ).

\section{Analytical methods}

All water used was initially filtered through a $200 \mu \mathrm{m}$ mesh net to remove large particulate material and zooplankton.

\section{Chlorophyll a}

A small sample of approximately $5 \mathrm{ml}$ of the filtered seawater was placed in a Turner Model III fluorometer appropriate for chlorophyll a fluorescence (Holm-Hansen et al., 1965) and calibrated against chlorophyll a (Lorenzen, 1967). This gave an indication of the volume of seawater which was required for subsequent chlorophyll a extraction.

Total chlorophyll a in the $200 \mu \mathrm{m}$ fraction was determined following extraction onto a $0.45 \mu \mathrm{m}$ Nuclepore membrane. The proportion of chlorophyll $a$ in the phytoflagellates was determined following filtration through a $10 \mu \mathrm{m}$ Nuclepore filter, followed by filtration onto a $0.45 \mu \mathrm{m}$ membrane. The chlorophyll a in the $10 \mu \mathrm{m}$ fraction was then determined by difference. All filtration was carried out using a vacuum of $12 \mathrm{~cm} \mathrm{Hg}$. The filters were subsequently homogenized in a small volume of $90 \%$ acetone, centrifuged, rinsed with $90 \%$ acetone, and made up to $20 \mathrm{ml}$ prior to estimation with the fluorometer. Phaeopigments were detected on the same sample following addition of 2 drops of $10 \% \mathrm{HCl}$ (Lorenzen, 1966).

\section{Carbon}

Depending on the chlorophyll content, 100 to $1000 \mathrm{ml}$ of sample was filtered through a $25 \mathrm{~mm}$ Whatman GF/C glass fibre filter which had been pre-ashed for $6 \mathrm{~h}$ at $400^{\circ} \mathrm{C}$. The filters were stored at $-20^{\circ} \mathrm{C}$ and then oven-dried at $55^{\circ} \mathrm{C}$ prior to analysis for particulate carbon in a Carlo Erba elemental analyzer (Model $1106)$ calibrated with cyclohexanone $(20.14 \% \mathrm{~N}$; $51.79 \%$ C).
The filtrate was used to estimate dissolved organic carbon. Triplicate samples of $8 \mathrm{ml}$ were transferred to precombusted $15 \mathrm{ml}$ glass vials to which $75 \mu \mathrm{l} 1 \mathrm{~N} \mathrm{HCl}$ was added to dispel inorganic carbon as $\mathrm{CO}_{2}$. The vials were then sealed with Teflon-lined caps and stored at $-20^{\circ} \mathrm{C}$. Dissolved organic carbon was then measured as $\mathrm{CO}_{2}$ by the $\mathrm{u} / \mathrm{v}$ photo-oxidation method of Collins and Williams (1977) as modified by Gershey et al. (1979). Potassium oxalate (Analar grade) dissolved in carbon-free $\mathrm{u} / \mathrm{v}$ irradiated distilled water was used as a standard.

\section{Numbers and biomass of micro-organisms}

\section{Bacteria}

Two separate samples, one of $10 \mathrm{ml}$ and the other of $160 \mathrm{ml}$, were taken from the NIO bottles and placed in autoclaved vessels together with Analar glutaraldehyde to a final concentration of $2.5 \%$. The $10 \mathrm{ml}$ sample was used for bacterial counts whilst the larger volume of $160 \mathrm{ml}$ was used as necessary for replicate numbers and biomass estimates.

Bacterial numbers were estimated using an epifluorescence direct counting technique (AODC: Hobbie et al., 1977; Daley, 1979; Linley et al., 1981). The relative frequency and mean volumes of bacteria in enlarged photographs of acridine orange stained cells were obtained from the mean of 100 or more of each cell type for up to 6 cell shape/volume categories (see also Fuhrman, 1981). Carbon:wet biomass ratios for bacteria are known to vary considerably from 0.079 in the heterogeneous populations of small bacteria from natural waters (Ferguson and Rublee, 1976; Bowden, 1977) to 0.121 (Watson et al., 1977) and 0.129 (Krambeck et al., 1981) for cultured bacteria. Bacterial biomass was therefore calculated from the cell volumes using a specific gravity of $1.1 \mathrm{~g} \mathrm{~cm}^{-3}$ (Doetsch and Cook, 1973) and the generally used ratio of carbon:wet biomass of 0.1 (Troitsky and Sorokin, 1967; Straškrabová and Sorokin, 1972), which is the approximate mean of the values cited above.

Replicate bacterial counts and the relative frequencies of different cell types gave maximum standard deviations of $\pm 4.5 \%$ and $6.7 \%$ respectively, whilst the standard errors of the biovolume estimates ranged from $3.7 \%$ to $9.3 \%$ of the mean values for the various cell types calculated separately.

\section{Protozoa}

Samples of $100 \mathrm{ml}$ were taken from the $20 \mathrm{l}$ pumped water bottles and placed in glass bottles together with 
$1 \mathrm{ml} 1 \%$ Lugol's iodine solution. Depending on the chlorophyll values, 10 or $100 \mathrm{ml}$ samples were allowed to settle onto counting chambers after which total cell counts were made with a Wild inverted microscope at $\times 10$ magnification. Flagellates were counted from one traverse on $\times 40$ magnification. After species identification, cell volumes were obtained from Larrance and Kovala (1966) and the carbon equivalent was calculated from Eppley et al. (1970).

\section{RESULTS}

\section{Standing stocks of bacteria}

The mean values and overall range of the numbers of bacteria in relation to dissolved organic carbon, chlorophyll a and particulate carbon in the water column from 4 different stations in the western English Channel are shown in Table 1. There is evidently a general correspondence between high bacterial numbers of $12.8 \times 10^{5}$ cells $\mathrm{ml}^{-1}$ (range 2.63 to $24.0 \times 10^{5}$ cells $\mathrm{ml}^{-1}$ ) in regions where the dissolved organic carbon, chlorophyll $a$ and particulate carbon are high, as at frontal station $(\mathrm{F})$, declining to only $2.91 \times 10^{5}$ cells $\mathrm{ml}^{-1}$ (range 2.28 to $3.94 \times 10^{5}$ cells $\mathrm{ml}^{-1}$ ) in the stratified waters of station (E5). These values are in agreement with the high numbers of $18.5 \times 10^{5}$ cells $\mathrm{ml}^{-1}$ (range 5.0 to $50 \times 10^{5}$ cells $\mathrm{ml}^{-1}$ ) recorded for productive coastal waters off Long Island, N.Y. by Ferguson and Palumbo (1979), and $19.6 \times 10^{5}$ cells $\mathrm{ml}^{-1}$ (range 5.2 to $59.8 \times 10^{5}$ cells $\mathrm{ml}^{-1}$ ) recorded by Zimmermann (1977) for the Kiel Bight. In contrast, lower values of 0.6 to $6.5 \times 10^{5}$ cells $\mathrm{ml}^{-1}$ have been recorded in the oligotrophic waters of McMurdo Sound, Antarctica, by Hodson et al. (1981) and 1.0 to $7.0 \times 10^{5}$ cells $\mathrm{ml}^{-1}$ in the Gulf of Mexico (Ferguson, 1981).
The standing stocks of bacteria and the corresponding values for chlorophyll a, dissolved organic carbon and particulate carbon are shown in relation to depth for frontal Station (F) in Table 2. The first and most obvious feature is that bacterial numbers decline from 17.6 to $18.8 \times 10^{5} \mathrm{cells} \mathrm{m}^{-1}$ in the surface waters to 2.3 to $2.73 \times 10^{6}$ cells $\mathrm{ml}^{-1}$ at depths below $20 \mathrm{~m}$. This, and the fact that the surface waters are dominated by large rods with a mean volume of $0.22 \mu \mathrm{m}^{3}$, results in a sharp decline in the bacterial biomass from the surface waters towards the deeper waters below the thermocline where cocci become the dominant morphological types (see also Holligan et al., 1983). The larger size and greater abundance of rod-shaped bacteria in the euphotic zone at Station $(F)$ suggests that the bacteria may be limited by the availability of dissolved organic carbon from the phytoplankton since cocci are generally characteristic of waters with low nutrient availability (see Wiebe and Pomeroy, 1972; Ferguson and Rublee, 1976; Hoppe, 1976; Fuhrman et al., 1980; Fuhrman and Azam, 1982).

The regression equations for bacterial numbers and carbon versus chlorophyll a, dissolved organic carbon and particulate carbon are also shown in Table 2. As might be anticipated, despite the fact that availability of dissolved organic carbon could control bacterial numbers and biomass in the water column, it is not correlated well with bacterial abundance since the residual pool of dissolved organic carbon in the water is merely a reflection of the balance between release from phytoplankton and uptake by the bacteria. An inverse correlation could indeed be expected under equilibrium conditions where the bacterial uptake of dissolved organic carbon is equal to the rate of release from the phytoplankton source. In contrast, highly significant correlations are obtained between both bacterial numbers and biomass and the standing stocks of phytoplankton as indicated by chlorophyll a. There is also a good correlation with particulate carbon as

Table 1 . Summary of mean values and ranges of bacterial numbers $\left(\times 10^{5} \mathrm{cells} \mathrm{m}^{-1}\right)$, dissolved organic carbon (DOC mg m $\left.{ }^{-3}\right)$ particulate carbon ( $\left.\mathrm{PC} \mathrm{mg} \mathrm{m} \mathrm{m}^{-3}\right)$ and chlorophyll a $\left(\mathrm{mg} \mathrm{m}^{-3}\right)$ recorded at 4 stations $(0$ to $60 \mathrm{~m}$ only) in the English Channel Samples taken between 22.7. and 2.8.81 at Stations (F), (E5) and (M) and between 6. 4. and 4. 5. 82 at Station (A.1). For details see p. 78

\begin{tabular}{|cccccc|}
\hline Station & & $\begin{array}{c}\text { Bacteria } \\
\left(\times 10^{5} \text { cells } \mathrm{ml}^{-1}\right)\end{array}$ & $\begin{array}{c}\text { DoC } \\
\left(\mathrm{mg} \mathrm{m}^{-3}\right)\end{array}$ & $\begin{array}{c}\text { Chlorophyll } a \\
\left(\mathrm{mg} \mathrm{m}^{-3}\right)\end{array}$ & $\begin{array}{c}\text { PC } \\
\left(\mathrm{mg} \mathrm{m}^{-3}\right)\end{array}$ \\
\hline (F) & Mean & 12.8 & 1509 & 10.63 & 1052 \\
& Range & $2.63-24.0$ & $1090-1963$ & $0.58-26.22$ & $127-2471$ \\
(E5) & Mean & 2.91 & 1320 & 0.37 & 177 \\
& Range & $2.28-3.94$ & $933-1520$ & $0.12-1.76$ & $79-404$ \\
(M) & Mean & 5.18 & 1350 & $0.10-2.29$ & 207 \\
(A1) & Range & $3.18-6.80$ & $940-2080$ & 1.83 & $154-350$ \\
& Mean & 3.49 & 1195 & $0.36-6.75$ & 323.3 \\
& Range & $7.30-11.5$ & $980-1309$ & & $138-681$ \\
\hline
\end{tabular}


Table 2. Vertical profile of bacterial numbers $\left(\times 10^{5}\right.$ cells $\left.\mathrm{ml}^{-1}\right)$ and carbon equivalent of bacterial biomass $\left(\mathrm{mg} \mathrm{m}^{-3}\right)$, chlorophyll a $\left(\mathrm{mg} \mathrm{m}^{-3}\right)$, dissolved organic carbon (DOC $\mathrm{mg} \mathrm{m}^{-3}$ ) and particulate carbon ( $\mathrm{PC} \mathrm{mg} \mathrm{m}^{-3}$ ) at frontal Station (F) taken on 2.8 . 81 with N.I.O. bottles. For details, see p. 78. Equations for regressions relating bacterial numbers and bacterial carbon to chlorophyll $a$, dissolved organic carbon and particulate carbon are also shown

\begin{tabular}{|c|c|c|c|c|c|c|c|c|}
\hline \multirow[t]{2}{*}{$\begin{array}{l}\text { Depth } \\
(\mathrm{m})\end{array}$} & \multicolumn{2}{|c|}{$\begin{array}{c}\text { Standing stocks of } \\
\text { bacteria }\end{array}$} & \multicolumn{2}{|c|}{$\begin{array}{l}\text { Chlorophyll } a \\
\left(\mathrm{mg} \mathrm{m}^{-3}\right)\end{array}$} & \multicolumn{2}{|c|}{$\begin{array}{c}\text { DOC } \\
\left(\mathrm{mg} \mathrm{m}^{-3}\right)\end{array}$} & \multicolumn{2}{|c|}{$\begin{array}{c}\mathrm{PC} \\
\left(\mathrm{mg} \mathrm{m}^{-3}\right)\end{array}$} \\
\hline & $\begin{array}{l}\text { No } \times 10^{5} \\
\left(\text { cells } \mathrm{ml}^{-1}\right)\end{array}$ & \multicolumn{3}{|l|}{$\begin{array}{l}\text { Carbon } \\
\mathrm{mg} \mathrm{m}^{-3}\end{array}$} & & & & \\
\hline 4 & 18.8 & 40.0 & \multicolumn{2}{|c|}{26.22} & \multicolumn{2}{|c|}{1450} & \multicolumn{2}{|l|}{2471} \\
\hline 12 & 17.1 & 28.1 & \multicolumn{2}{|c|}{21.34} & \multicolumn{2}{|c|}{1430} & \multicolumn{2}{|l|}{2151} \\
\hline 14 & 17.3 & 20.1 & \multicolumn{2}{|c|}{18.91} & \multicolumn{2}{|c|}{1936} & \multicolumn{2}{|l|}{1592} \\
\hline 16 & 18.3 & 21.3 & \multicolumn{2}{|c|}{12.53} & \multicolumn{2}{|c|}{1846} & \multicolumn{2}{|l|}{1971} \\
\hline 18 & 17.9 & 20.8 & \multicolumn{2}{|c|}{19.72} & \multicolumn{2}{|c|}{1956} & \multicolumn{2}{|l|}{1541} \\
\hline 20 & 17.6 & 20.4 & \multicolumn{2}{|c|}{17.56} & \multicolumn{2}{|c|}{1963} & \multicolumn{2}{|l|}{1963} \\
\hline 22 & 2.63 & 3.1 & & & & & 236 & \\
\hline 25 & 2.81 & 2.3 & & & & & 127 & \\
\hline 35 & 2.73 & 2.2 & & & & & 142 & \\
\hline $\begin{array}{l}\text { Equation of } \\
\text { regression }\end{array}$ & & $\begin{array}{l}\text { terial numbers } \\
\qquad \mathrm{Y}=\mathrm{b}\end{array}$ & $\begin{array}{l}10^{5} \text { cells I } \\
+ \text { a) }\end{array}$ & & & $\begin{array}{l}\text { erial carb } \\
\qquad Y=b\end{array}$ & $\begin{array}{l}\left(\mathrm{mg} \mathrm{m}^{-3}\right) \\
\text { - a) }\end{array}$ & \\
\hline & & a & r & $\mathrm{N}$ & & & & \\
\hline Chlorophyll a $\left(\mathrm{mg} \mathrm{m}^{-3}\right)$ & & +3.384 & $0.936^{\cdots}$ & 9 & 1.243 & +1.190 & $0.957 \cdots$ & 9 \\
\hline $\operatorname{DOC}\left(\mathrm{mg} \mathrm{m}^{-3}\right)$ & & -17.224 & $0.713^{*}$ & 9 & 0.015 & +7.394 & 0.348 & 9 \\
\hline $\mathrm{PC}\left(\mathrm{mg} \mathrm{m}^{-3}\right)$ & & +2.211 & $0.962 \cdots$ & 9 & 0.014 & -3.087 & $0.881 \cdots$ & 9 \\
\hline
\end{tabular}

Table 3. Vertical profile of bacterial numbers $\left(\times 10^{5}\right.$ cells $\left.\mathrm{ml}^{-1}\right)$ and corresponding chlorophyll a distribution $\left(\mathrm{mg} \mathrm{m}^{-3}\right)$ at 4 separate stations in the Southern Benguela upwelling region (Nimbus G cruise, see text) between 11. 11. and 14.11.78. Distribution of bacteria and chlorophyll a in relation to depth (m) at Station P34 in the Celtic Sea on 13. 8. 80 is also shown. For details see $p .78$. Equations for the regressions ( $Y=b \cdot x+$ a) are shown

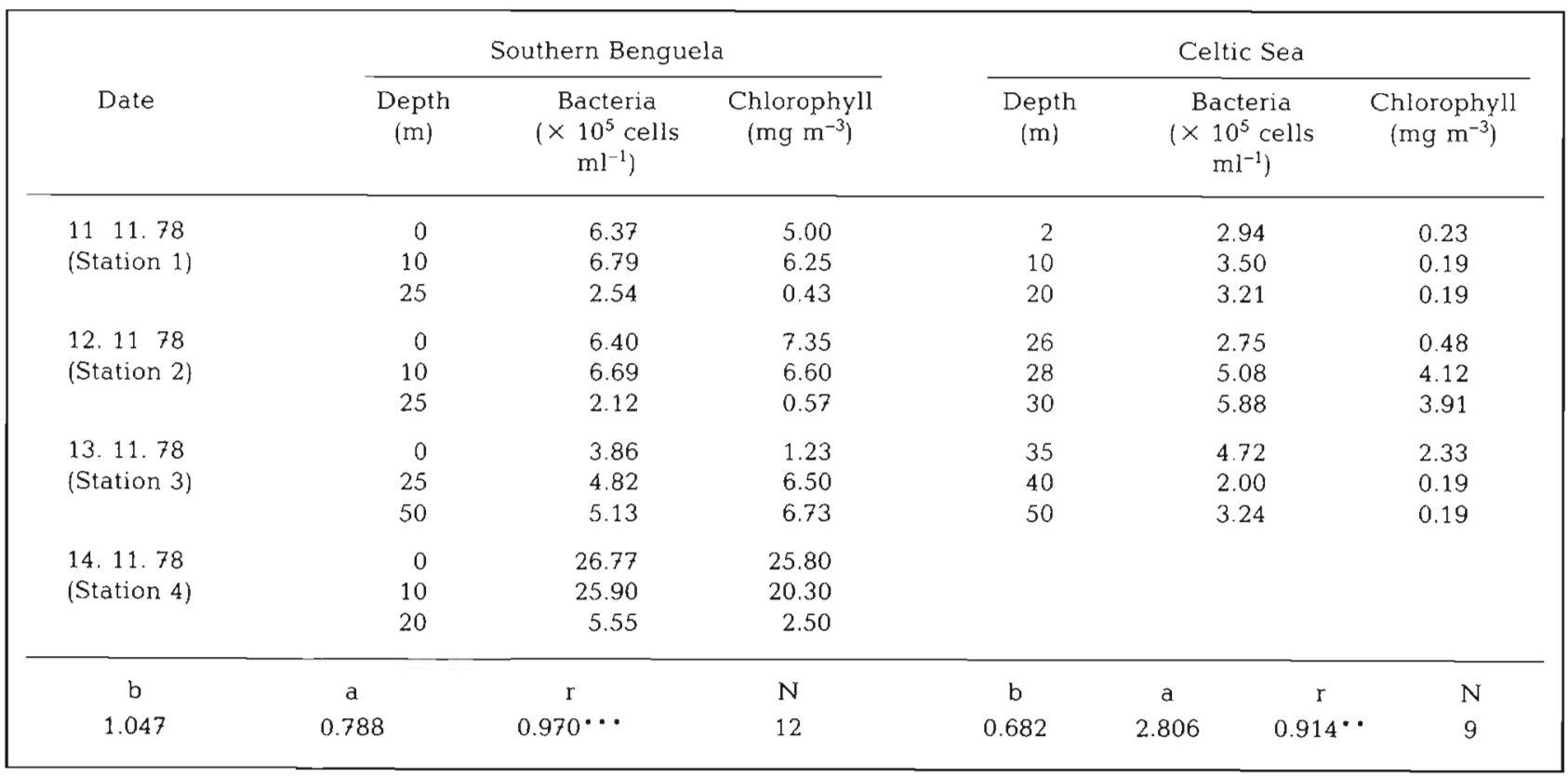

might be expected in a water column where the predominant particulate matter is phytoplankton. Significant correlations between bacterial numbers and both chlorophyll a and particulate carbon have also been recorded by Fuhrman et al. (1980) and with chlorophyll a by Ferguson and Palumbo (1979), although in neither case is the full regression equation given.

Bacterial numbers showed as good a correlation as the carbon equivalent of bacterial biomass in both the productive waters at the frontal station (F) off the 
western English Channel as well as in other sea areas Table 3 shows, for example, the mean values for bacterial numbers and chlorophyll a at 3 different depths from 3 separate sample hauls and from 4 different stations along the track of the Nimbus $G$ cruise in the southern Benguela upwelling region off the Cape Peninsula, South Africa (Fig. 1b). Also shown is the depth profile for bacterial numbers and chlorophyll a in the Celtic Sea (Station P34, Fig. 1a) from which it will be seen that bacteria again reach their maximum numbers in the chlorophyll a maximum zone, which in this case was in the depth range 28 to $30 \mathrm{~m}$. The regression equations for both sites are shown in Table 3 and support the results of Ferguson (1981) who found that the regression relating bacterial numbers $\left(\times 10^{6}\right.$ cells $\mathrm{ml}^{-1}$ ) in the waters of the Gulf of Mexico to chlorophyll a $\left(\mathrm{mg} \mathrm{l}^{-1}\right)$ was of the form: bacterial numbers $=0.352 \log _{e}$ chlorophyll $a+0.697 ; n=8$, $\mathrm{r}=0.968$.

Because the regression equations for the 3 sampling sites are apparently similar, it is of interest to compare those obtained for cruises including stratified (Station E5), mixed (Station M) and frontal (Station F) waters off the English Channel, nearshore channel waters (Station A1), Celtic Sea (Station P34), as well as those for the Benguela upwelling region (Nimbus $G$ cruise) and for the Gulf of Mexico (from Ferguson, 1981). These are summarized in Table 4 which yielded the following regression for the pooled data from all our cruises: bacterial Numbers $\left(\times 10^{5} \mathrm{ml}^{-1}\right)=0.822$ chlorophyll $a$ $+2.348\left(\mathrm{n}=84 ; \mathrm{r}=0.935^{\cdots} \cdots\right)$.

The common regression, together with the data to which it has been fitted, is shown in Fig. 2, and the regression equations for chlorophyll a values 0 to 10 and 10 to $30 \mathrm{mg} \mathrm{m}^{-3}$ (calculated separately), are also illustrated for comparison. Although there is some difference in the level of the 2 lines, it is clear that bacterial numbers in a variety of marine waters are correlated with chlorophyll $a$ in the water column. This may reflect the availability of dissolved organic matter released either by the living phytoplankton, or following disruption of the cells, even though no good correlation can be established between the residual nonutilized pool of dissolved organic carbon and bacterial numbers in the water column. It is also apparent that despite the similarity of the slopes of regression equations for chlorophyll a values 0 to 10 and 10 to $30 \mathrm{mg}$ $\mathrm{m}^{-3}$, the equation for the upper range has a significantly higher intercept value, suggesting that there may be additional organic substrates suitable for

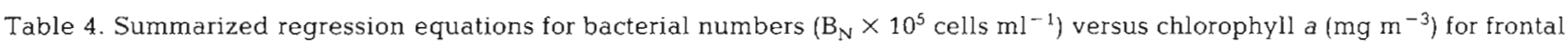
$(F)$, mixed water (M) and stratified (E5) waters off the western approaches of the English Channel (22.7. to 2. 8. 81). Data for the southern Benguela upwelling region, off the Cape Peninsula, South Africa (11.11. to 14.11.78) and the equation derived by Ferguson (1981) for the Gulf of Mexico are also shown, as well as a series of regressions for coastal waters of the English Channel (Station A1 from 6. 4.to 4. 5. 82) and the Celtic Sea (Station P34 on 13. 8. 80). The regression for the pooled data for all regions including the Gulf of Mexico is also shown

\begin{tabular}{|c|c|c|c|c|}
\hline Location & Regression equation & Chlorophyll range & $\mathrm{r}$ & $\mathrm{n}$ \\
\hline \multicolumn{5}{|l|}{ English Channel } \\
\hline Station (F) & $Y=0.713 X+3.384$ & $0.58-26.22$ & $0.936^{\cdots} \cdot$ & 9 \\
\hline Station (M) & $Y=3.028-0.324 X$ & $0.10-2.29$ & -0.311 & 9 \\
\hline Station (E 5) & $Y=9.400-3.369 X$ & $0.12-1.76$ & -0.497 & 9 \\
\hline Pooled Data & $Y=0.739 X+2.867$ & $0.10-26.22$ & $0.965^{\cdots}$ & 27 \\
\hline Benguela upwelling & $Y=1.047 X+0.788$ & $0.43-25.80$ & $0.970^{\circ} \cdots$ & 12 \\
\hline $\begin{array}{l}\text { Gulf of Mexico } \\
\text { (From Ferguson, 1981) }\end{array}$ & $Y=0.72 X+5.188$ & $0.17-18.00$ & $0.888 \%$ & 8 \\
\hline \multicolumn{5}{|l|}{ English Channel } \\
\hline \multicolumn{5}{|l|}{ Station (A 1) } \\
\hline 6.4 .82 & $Y=1.472 X+1.250$ & $0.36-1.49$ & $0.907^{\cdots}$ & 7 \\
\hline 13. 4.82 & $Y=0.514 X+2.456$ & $0.74-1.59$ & 0.421 & 7 \\
\hline 27.4 .82 & $Y=0.301 X+3.044$ & $2.49-6.75$ & $0.610^{\cdots}$ & 7 \\
\hline 4. 5.82 & $Y=0.633 X+1.441$ & $2.26-4.37$ & $0.898^{\cdots}$ & 7 \\
\hline Pooled Data & $Y=0.439 X+2.307$ & $0.36-6.75$ & $0.790 \cdots$ & 28 \\
\hline $\begin{array}{l}\text { Celtic Sea } \\
\text { Station (P34) }\end{array}$ & $Y=0.682 X+2.806$ & $0.19-4.12$ & $0.914^{\cdots}$ & 9 \\
\hline Total pooled data & $Y=0.822 X+2.348$ & $0.10-26.22$ & $0.935 \cdots$ & 84 \\
\hline
\end{tabular}


bacterial growth associated with the larger standing stocks of phytoplankton, which are not directly related to chlorophyll a concentration.

It should be pointed out, however, that where the bacterial numbers exceed $15.0 \times 10^{5}$ cells $\mathrm{ml}^{-1}$, corresponding to a chlorphyll concentration of approximately $10 \mathrm{mg} \mathrm{m}^{-3}$, and a bacterial density suitable for efficient bactivory (Fenchel, 1983), the close cyclic coupling which is likely to occur between heterotrophic microflagellates and their bacterial prey may result in very variable bacterial standing stocks (Fenchel, 1982d). Thus, for most purposes, we regard the relationship as useful in indicating the probable bacterial numbers over the chlorophyll a range $2 \mathrm{mg} \mathrm{m}^{-3}$ to $7-10 \mathrm{mg} \mathrm{m}^{-3}$, as indicated in Fig. 2.

\section{Standing stocks of Protozoa}

The carbon equivalent of the standing stocks of bacteria, flagellates and ciliates as a function of depth at

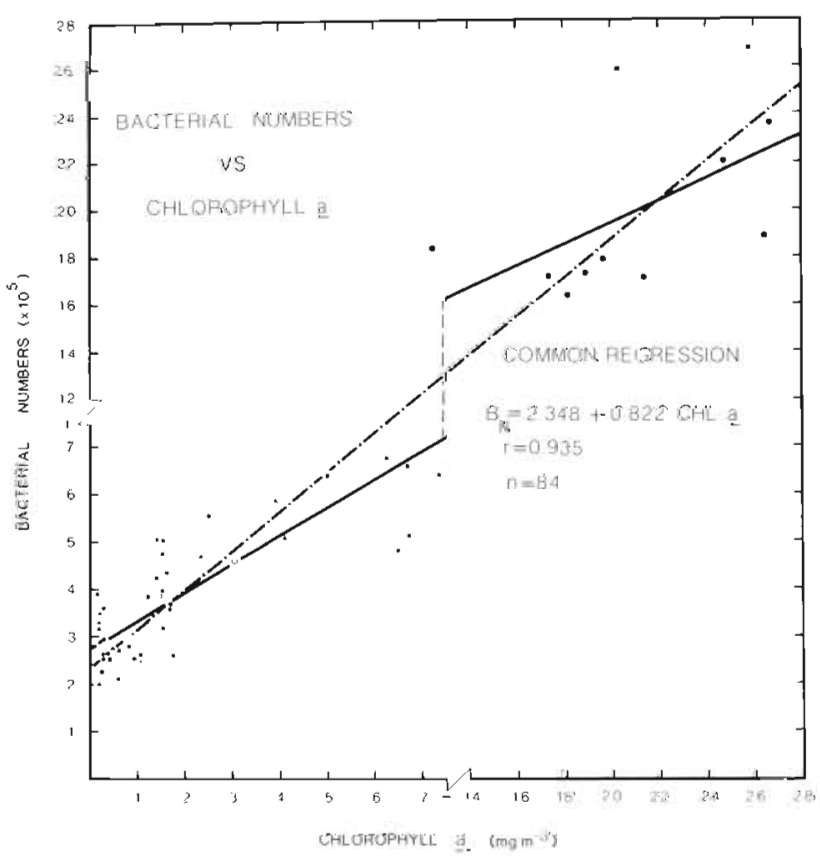

Fig. 2. Regression relating the bacterial numbers $\left(B_{N} 10^{5}\right.$ cells $\left.\mathrm{ml}^{-1}\right)$ to chlorophyll a concentration $\left(\mathrm{mg} \mathrm{m}^{-3}\right)$ for pooled data from English Channel, Celtic Sea and southern Benguela upwelling region (see also Table 4). Regression equations for chlorophyll a values of $<10$ and $>10 \mathrm{mg} \mathrm{m}^{-3}$ calculated separately, are shown for comparison. Solid dots (English Channel Stations F, M and E5), solid squares (Benguela upwelling stations), open dots (English Channel nearshore Station A1), triangles (Celtic Sea). The regression equations for 0 to 10 and 10 to $30 \mathrm{mg} \mathrm{m}^{-3}$ chlorophyll a are respectively: $\mathrm{B}_{\mathrm{N}}=2.732+0.591$ chl $a \quad\left(\mathrm{n}=73 ; \quad \mathrm{r}=0.636^{\cdots} \cdot\right)$ and $\mathrm{B}_{\mathrm{N}}=10.50+0.451 \mathrm{chl} a(\mathrm{n}=11 ; \mathrm{r}=0.496)$, and that for the pooled data (dotted line) is Bacterial numbers $=0.822$. Chlorophyll $a+2.348\left(n=84 ; r=0.935^{\cdots} \cdot\right)$ frontal Station (F), mixed water Station (M) and the stratified Station (E5) off the western English Channel is shown in Table 5. The proportion of carbon in the phototrophic microflagellates was estimated from the product of chlorophyll a $\left(\mathrm{mg} \mathrm{m}^{-3}\right)$ in the $10 \mu \mathrm{m}$ fraction (p. 79) and a carbon: chlorophyll a ratio of 25.5, which is the mean of a range of 19 to 32 obtained by Parsons et al. (1961) for Chlorophyceae. These values were subtracted from total microflagellate carbon (p. 79) to give estimates of heterotrophic microflagellate carbon.

It is apparent that the proportion of carbon in the standing stocks of heterotrophic microflagellates range from approximately 8 to $45 \%$ of the total flagellates at Stations (F), (M) and (E5). It can also be seen that the ciliates are dominated by tintinnids which may reach a similar biomass to that of the flagellates. The carbon in the standing stock of heterotrophic microflagellates themselves represents 4 to $26 \%$ of the carbon in the bacteria which form their principal prey (with the exception of surface waters of E5, where the figure is $78 \%$ [see Table 5 and Fenchel, 1982d]). We have noted similar proportional relationships consistently in experimental studies on the microbial succession which colonizes plant detritus from a variety of sources (Linley et al., 1981; Linley and Newell, 1981; Newell et al., 1981).

The relation between the carbon in the standing stock of heterotrophic microflagellates and that in the bacteria for the 3 sampling sites is shown in Fig. 3 . The regression equation is $\log _{10}$ Flagellate carbon ( $\mathrm{mg}$ $\left.\mathrm{m}^{-3}\right)=0.717 \log _{10}$. Bacterial carbon $\left(\mathrm{mg} \mathrm{m} \mathrm{m}^{-3}\right)-0.675$

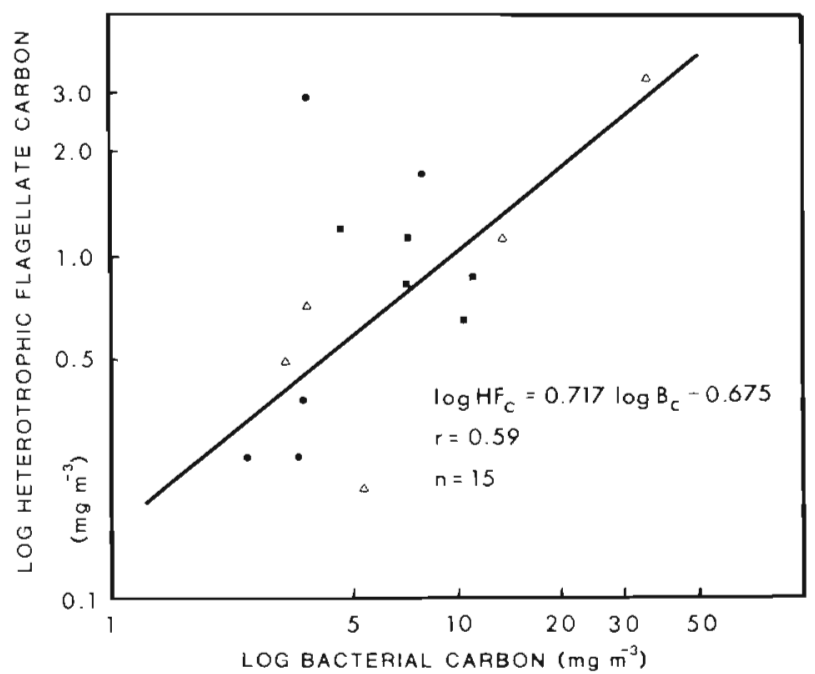

Fig. 3. Regression relating standing stocks of heterotrophic flagellates ( $\log _{10} \mathrm{HF}_{\mathrm{C}}, \mathrm{mg} \mathrm{C} \mathrm{m} \mathrm{m}^{-3}$ ) to standing stocks of bacteria ( $\log _{10} \mathrm{~B}_{\mathrm{C}}, \mathrm{mg} \mathrm{C} \mathrm{m}^{-3}$ ) for pooled data shown in Table 5. Triangles (Station F), solid squares (Station M) and closed circles (Station E5). The regression fitted to data for all 3 channel stations is: $\log _{10} \mathrm{HF}_{\mathrm{C}}=0.717 \log _{10} \mathrm{~B}_{\mathrm{C}}-0.675$ $\left(\mathrm{n}=15 ; \mathrm{r}=0.59^{*}\right)$ 


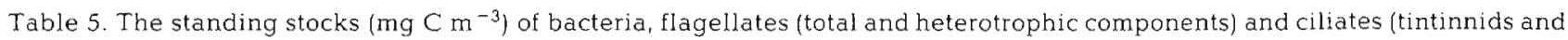
others) at frontal (Station F), mixed (Station M) and stratified waters (Station ES) off the western approaches to the English Channel. Data collected in collaboration with Dr. P. M. Holligan (Marine Biological Association, Plymouth) on R. V Frederick Russell cruise 22.7. to 2.8.81, from pumped water profiles (c. f. Table 2 which is for N.I.O. bottle samples).

\begin{tabular}{|c|c|c|c|c|c|c|c|}
\hline \multirow[t]{2}{*}{ Station } & \multirow{2}{*}{$\begin{array}{l}\text { Depth } \\
(\mathrm{m})\end{array}$} & \multirow[t]{2}{*}{ Bacteria } & \multicolumn{2}{|c|}{ Flagellates } & \multirow{2}{*}{$\frac{\text { Heterotrophic flagellates }}{\text { Bacteria }} \cdot 100$} & \multicolumn{2}{|c|}{ Ciliates } \\
\hline & & & Total & Heterotrophs & & Tintinnids & Others \\
\hline \multirow[t]{5}{*}{$\mathrm{F}$} & $12-2$ & 35.2 & 26.06 & 3.28 & 9.32 & 2.28 & 0.066 \\
\hline & $24-12$ & 13.4 & 14.01 & 1.26 & 9.40 & 2.66 & 0.350 \\
\hline & $36-24$ & 5.4 & 2.25 & 0.21 & 3.89 & 1.24 & 0.145 \\
\hline & $48-36$ & 3.7 & 1.99 & 0.72 & 19.46 & 3.26 & 0.443 \\
\hline & $60-48$ & 3.2 & 1.77 & 0.49 & 15.31 & 2.74 & 0.400 \\
\hline \multirow[t]{5}{*}{$M$} & $12-2$ & 10.3 & 6.43 & 0.65 & 6.31 & 2.66 & 0.000 \\
\hline & $24-12$ & 7.1 & 6.43 & 0.82 & 11.55 & 5.20 & 0.010 \\
\hline & $36-24$ & 7.2 & 6.72 & 1.11 & 15.42 & 4.30 & 0.005 \\
\hline & $48-36$ & 10.9 & 6.48 & 0.87 & 7.98 & 4.12 & 0.071 \\
\hline & $60-48$ & 4.6 & 6.81 & 1.20 & 26.09 & 3.15 & 0.000 \\
\hline \multirow[t]{5}{*}{ ES } & $12-2$ & 3.8 & 6.54 & 2.97 & $78.16^{\circ}$ & 2.36 & 0.000 \\
\hline & $24-12$ & 7.9 & 10.65 & 1.73 & 21.90 & 29.70 & 0.000 \\
\hline & $36-24$ & 3.5 & 3.32 & 0.26 & 7.43 & 2.88 & 0.000 \\
\hline & $48-36$ & 3.6 & 2.67 & 0.38 & 10.56 & 1.81 & 0.000 \\
\hline & $60-48$ & 2.5 & 2.04 & 0.26 & 10.40 & 2.36 & 0.000 \\
\hline
\end{tabular}

$\left(\mathrm{n}=15 ; \mathrm{r}=0.59^{*}\right)$ which is similar to the relationships we have obtained from microbial successions on several different sources of phytoplankton debris (Newell et al., 1981). Recalculation of the data presented by Fenchel (1982d) suggests that under natural conditions in the Limfjord, Denmark, the proportion of heterotrophic microflagellates to bacterial prey also ranges from 5.7 to $15.9 \%$ (mean $9.6 \%$ ).

\section{DISCUSSION}

Because there have been a relatively large number of recent studies on bacterial carbon production in a variety of marine habitats, and because we also have some information on the likely consumption requirements of both the bacteria and the heterotrophic microflagellates, it is now possible to make some estimates on the proportion of phytoplankton carbon which flows through the microheterotrophic consumer community.

The range of values recently reported for bacterial production in a variety of marine systems has been summarized by Newell and Christian (1981) and includes estimates of 2 to $16 \mathrm{mg} \mathrm{C} \mathrm{m} \mathrm{m}^{-3} \mathrm{~d}^{-1}$ for coastal Baltic waters (Hagström et al., 1979), 0.72 to $72 \mathrm{mg} \mathrm{C}$ $\mathrm{m}^{-3} \mathrm{~d}^{-1}$ for coastal waters in northwestern USA (Fuhrman and Azam, 1980), 19.2 to $177.6 \mathrm{mg} \mathrm{C} \mathrm{m}{ }^{-3} \mathrm{~d}^{-1}$ for nearshore waters in Georgia, USA (Newell and Christian, 1981) and 0 to $78 \mathrm{mg} \mathrm{C} \mathrm{m}^{-3} \mathrm{~d}^{-1}$ for the Kiel Fjord and Bight (Meyer-Reil, 1977). Although a great variability exists according to method and area, the mean value for maximal bacterial production $\left(\mathrm{P}_{\max }\right)$ for the data summarized by Newell and Christian (1981) is approximately $75 \mathrm{mg} \mathrm{C} \mathrm{m}^{-3} \mathrm{~d}^{-1}$. This value is very close to that which we have recorded in batch cultures of natural heterogeneous populations of marine bacteria in seawater to which phytoplankton debris was added to a concentration which is similar to that in phytoplankton blooms at Station (F) in the English Channel (Newell et al., 1981).

In these experiments, the results of which have been recalculated in Table 6 , we were able to measure concurrently both the increase in the carbon equivalent of bacterial biomass, and thus obtain a measure of bacterial production during the logarithmic growth phase, and also measure carbon utilization from the detrital source. This allows calculation of the carbon equivalent of the 'growth yield' or carbon conversion efficiency (carbon incorporated into bacterial biomass carbon used from the detrital source ${ }^{-1} \times 100$ ) which, as can be seen from Table 6 , was approximately $10 \%$. Most values for the growth yield of bacteria have been obtained either from continuous cultures in enriched media or from the kinetics of uptake of low concentrations of ${ }^{14} \mathrm{C}$-labelled simple organic substrates and have generally been found to exceed $50 \%$ (see Payne, 1970; Joint and Morris, 1982). However, as pointed out by Fenchel and Jørgensen (1976), and more recently by Payne and Wiebe (1978), there is now a good deal of 
Table 6. Bacterial production ( $\mathrm{mg} \mathrm{C} \mathrm{m}^{-3} \mathrm{~d}^{-1}$ ) and carbon conversion efficiency ([mg C incorporated into bacterial biomass. mg $\mathrm{C}$ used from detrital source ${ }^{-1}$ ] $\times 100$ ) based on phytoplankton cell debris incubated in non-enriched seawater at $10^{\circ} \mathrm{C}$. Data recalculated from Newell et al. (1981)

\begin{tabular}{|c|c|c|c|}
\hline Detrital source & $\begin{array}{l}\text { Detritus concentration } \\
\qquad\left(\mathrm{mg} \mathrm{C} \mathrm{l}^{-1}\right)\end{array}$ & $\begin{array}{l}\text { Bacterial production } \\
\left(\mathrm{mg} \mathrm{C} \mathrm{m}^{-3} \mathrm{~d}^{-1}\right)\end{array}$ & $\begin{array}{l}\text { Carbon conversion } \\
\text { efficiency }(\%)\end{array}$ \\
\hline \multicolumn{4}{|l|}{ Diatoms } \\
\hline Thalassiosira angstii & 12.12 & 127 & 13.48 \\
\hline Chaetoceros tricornutum & 13.02 & 79 & 8.04 \\
\hline Skeletonema costatum & 11.86 & 79 & 8.25 \\
\hline \multirow{4}{*}{$\begin{array}{l}\text { Dinoflagellates } \\
\text { Scrippsiella trochoidea } \\
\text { Isochrysis galbana }\end{array}$} & & & \\
\hline & 10.76 & 61 & 11.99 \\
\hline & $\underline{12.0}$ & $\underline{72}$ & 7.60 \\
\hline & $\bar{x}=\overline{11.95}$ & $\bar{X}=\overline{84}$ & $\bar{x}=\overline{9.90}$ \\
\hline
\end{tabular}

doubt to what extent these data can be applied to the transformation of the relatively high concentrations of complex detrital material which occur following episodic phytoplankton blooms in coastal waters. Quite apart from the fact that carbon conversion is enhanced by the amino acids, vitamins and casamino acids which are usually added to experimental incubation media (Payne and Williams, 1976; see also Newell, 1983), there is some doubt whether the ${ }^{14} \mathrm{CO}_{2}$ respired over a 1 to $2 \mathrm{~h}$ incubation period is proportional to the ${ }^{12} \mathrm{CO}_{2}$ respired (Hanson and Wiebe, 1977).

The only data comparable to those cited in Table 6 for the carbon conversion of phytoplankton debris by natural populations of marine bacteria are a series of studies which we have made on kelp detrital material (Linley and Newell, 1981; Lucas et al., 1981; Newell and Lucas, 1981; Stuart et al., 1982), and on detritus from the saltmarsh grasses Spartina alterniflora and Juncus roemerianus (Newell et al., 1983) which yield carbon conversion efficiency values of $8.8 \%$ to $13.6 \%$. These values are in good agreement with those recently reported by Robertson et al. (1982) who obtained a carbon equivalent of bacterial biomass of $4 \%$ of the detrital carbon used from the seagrass Thalassia and $16.1 \%$ of that from Syringodium (i.e. a mean of $10.05 \%$ ). It seems unlikely that the low values for carbon conversion of natural detrital material are due to an underestimate of bacterial production resulting from grazing by microflagellates, although apparently, they may consume up to $4.4 \%$ of bacterial production $h^{-1}$ over the first $21 \mathrm{~h}$ of incubation (Newell, 1983). In any event, it will be noted from Table 6 that our estimates of bacterial production in the presence of phytoplankton debris concentrations similar to the maximum encountered in a phytoplankton bloom situation are in striking accordance with those obtained by a variety of methods in other sea areas (see p. 84).

Although we have obtained values as high as $37 \%$ for the carbon conversion efficiency of bacterial populations utilizing detrital substrates with low $\mathrm{C} / \mathrm{N}$ ratio (Newell et al., 1983), it seems likely that a value of $10 \%$ represents the best estimate at the present time for the carbon conversion efficiency of the relatively high concentrations of complex detrital material which occur in phytoplankton blooms under natural conditions. We have therefore used a carbon conversion of $10 \%$ to estimate the consumption requirements of the bacteria in the water column. We recognize, however, that both the kinetics of uptake and the cell yield of heterogeneous populations of bacteria utilizing dissolved components of primary production at low substrate concentrations in oligotrophic waters may be different from that occurring in episodic blooms which characterize shelf waters. Indeed, there is some indirect evidence that a higher cell yield must occur in such waters (see p.87). Consumption requirements of the microflagellates are now well documented for genera of a variety of sizes from 20 to $200 \mu \mathrm{m}^{3}$ cell volume by Fenchel (1982d). The mean volume of bacteria consumed/volume of flagellate predator $24 \mathrm{~h}^{-1}$ is $16.98 \pm 3.13$ (see also Newell, 1983) and allows some estimates to be made of carbon flow from the bacteria to heterotrophic microflagellates in the pelagic community.

The overall carbon flow for the frontal (F), mixed (M) and stratified (E5) stations off the western approaches to the English Channel is summarized in Table 7. Bacterial production values for Station $(F)$, where the standing stock of phytoplankton and primary production is at its maximum, are available from (1) the mean of the maximum values recorded in the recent literature (see p. 84); (2) direct experimental studies of bacterial growth in batch cultures in the presence of phytoplankton debris at a concentration similar to that at frontal Station (F) (Newell et al., 1981; also Table 6); and (3) an estimate based on the carbon consumption requirements of the heterotrophic microflagellates 
(Newell and Christian, 1981). This assumes that (a) heterotrophic microflagellates in the size range 3 to $10 \mu \mathrm{m}$ are the only consumers of bacteria and (b) bacterial production is in equilibrium with grazing by microflagellates.

From Table 5 it is apparent that the non-tintinnid ciliates are present in insufficient quantity to represent significant bacterial grazers even if, as in the case of Uronema marinum, they may be capable of removal of up to 6 times their body weight per day in bacteria (Burkill, 1978). The tintinnids, which are quantitatively the dominant ciliates, in general only consume particles much larger than bacteria and are mainly dependent upon phytoplankton, including the flagellates (Spittler, 1973; Heinbokel, 1978; Fenchel, 1983), and although free-living bacteria may form a substan- tial portion of the diet of some larvaceans (Oikopleura dioica, for example; King et al., 1980), they were not a significant component of the English Channel zooplankton (Holligan et al., 1983). As phagotrophic microflagellates in the size range 3 to $10 \mu \mathrm{m}$ are the only organisms which can utilize natural concentrations of bacteria efficiently (Fenchel, 1983), they are therefore likely to be the principal, and probably only, bactivores in the present study.

Clearly then, if bacterial production is in equilibrium with grazing by microflagellates, the carbon requirements of the grazers (based on consumption rates of $16.98 \pm 3.14 \times$ their body volume $d^{-1}$ (Fenchel, 1982d; Newell, 1983), approximate to a conservative estimate of bacterial production, i.e. the mean values of 55.8, 12.6, and $40.0 \mathrm{mg} \mathrm{Cm}^{-3}$ for F, M and E5

Tabie 7. Standing stocks ( $\mathrm{mg} \mathrm{C} \mathrm{m} \mathrm{C}^{-3}$ ) and estimated consumption requirements $\left(\mathrm{mg} \mathrm{Cm}^{-3} \mathrm{~d}^{-1}\right.$ ) of bacteria in the euphotic zone of frontal (F), mixed (M) and stratified (E5) shelf waters off the English Channel. Bacterial production figures for the frontal station are based on: (1) mean of $\mathbf{P}_{\max }$ from the literature (see text), (2) experimental data for carbon production based on phytoplankton debris at a similar concentration to that at frontal station $F$ (Table 6) and (3) flagellate consumption requirements (see text). The latter value has additionally been used to estimate bacterial production at Stations (M) and (E5). Mean values for primary production were obtained from measurements on $2\left(^{\circ}\right)$ or $3\left(^{*}\right)$ consecutive days, and ranges include estimates from both $C^{14}$ and oxygen method determinations. [ ${ }^{+}$as $\%$ median value.] Data for primary production kindly made available by Dr. P. J. le B. Williams of the University of Southampton, and Dr. P. M. Holligan of the M.B.A., Plymouth

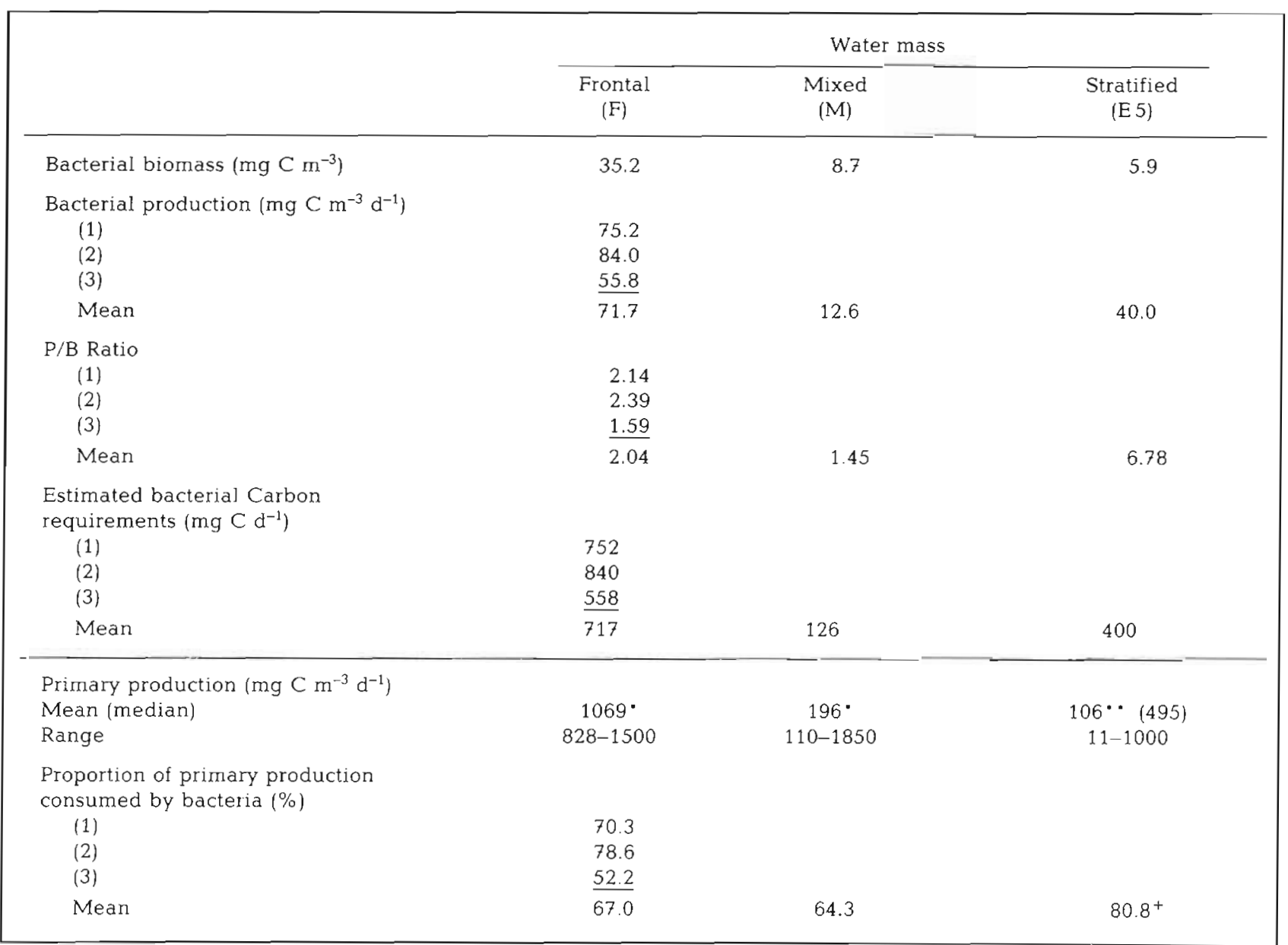


respectively. This would necessitate generation times of 8 to $19 \mathrm{~h}$, which are well within the range of the 3 to 48 h cited for productive coastal waters by Van Es and Meyer-Reil (1982) in their recent review, and yields bacterial production estimates consistent with the values summarized by Newell and Christian (1981) for a variety of coastal and shelf waters (see also p. 84).

The estimated bacterial carbon requirements at a conversion efficiency of $10 \%$ are thus $10 \times$ the production values or $717 \mathrm{mg} \mathrm{C} \mathrm{d}^{-1}$ based on all 3 estimations of bacterial production at Station (F), $126 \mathrm{mg} \mathrm{C} \mathrm{d}^{-1}$ at the mixed water Station (M) and $400 \mathrm{mg} \mathrm{C} \mathrm{d}^{-1}$ at Station E5. From this it can be seen that carbon consumption by bacteria accounts for 60 to $80 \%$ of the carbon fixed by primary production. This figure is in good agreement with that of Sorokin and Mikheev (1979), who have estimated that as much as 70 to $80 \%$ of total energy flux in the Peruvian upwelling system occurs through the bacteria and microprotozoa. In contrast, by assuming a conversion efficiency of $37 \%$ (obtained on low $\mathrm{C}$ : $\mathrm{N}$ plant debris, see Newell et al., 1983), the estimated bacterial carbon requirements amount to approximately 14 to $22 \%$ of primary production, which is similar to the results obtained by Wiebe and Smith (1977) who found that uptake of ${ }^{14} \mathrm{C}$-labelled exudates by bacteria is in equilibrium with its release from phytoplankton and amounts to about $25 \%$ of the carbon originally fixed by the phytoplankton (see also Hagström et al., 1979). It suggests that despite the relatively high dissipation of carbon, which we have measured from complex detrital sources in nonenriched media, carbon fixation by photosynthesis in the euphotic zone of productive coastal waters is well in excess of that required by the microheterotrophic community

Although there are relatively few detailed studies on the standing stocks of microplankton, including bacteria and heterotrophic microflagellates, in the open oceans, some general comparisons can be made between the results we have obtained for coastal phytoplankton bloom situations and likely carbon flow through the microheterotrophs in oligotrophic waters. The bacterial standing stocks in open oceans is likely to be of the order of 0.05 to $0.15 \times 10^{6}$ cells $\mathrm{ml}^{-1}$ (Sorokin, 1981). Assuming that a ratio of heterotrophic flagellates: bacterial prey of 0.05 to 0.15 recorded for coastal waters and experimental media occurs in oligotrophic waters (see also Linley and Newell, 1981; Newell et al., 1981; Fenchel, 1982d), and that the flagellates consume approximately 17 times their body volume of bacteria per day (Fenchel, 1982d), the carbon requirements of the flagellates would be $0.6-1.8 \mathrm{mg} \mathrm{C} \mathrm{m}^{-3} \mathrm{~d}^{-1}$. If the bacteria were converting the organic carbon available in oligotrophic waters with an efficiency of only $10 \%$, as we have recorded in the presence of high concentrations of phytoplankton debris, a primary production of 6.0 to $18 \mathrm{mg} \mathrm{C} \mathrm{m}^{-3} \mathrm{~d}^{-1}$ would be required to sustain the consumption requirements of the heterotrophic microflagellates, even if all carbon from primary production entered the microheterotrophic food chain. In fact, primary production is approximately 2.5 to $5.0 \mathrm{mg} \mathrm{C} \mathrm{m} \mathrm{m}^{-3} \mathrm{~d}^{-1}$ (Ryther, 1969), and probably $30 \%$ (but up to $60 \%$ ) enters the microbial food chain (Williams, 1981), suggesting that a bacterial carbon conversion of at least $50 \%$ is likely to occur in oligotrophic waters. This accords well with estimates based on experiments with low concentrations of ${ }^{14} \dot{\mathrm{C}}$-labelled substrates comparable with oligotrophic waters (see p. 84; Joint and Morris, 1982) and suggests that carbon flow through the microbial community may be different from that in the decomposition phase of phytoplankton blooms in coastal waters. Unfortunately, until there are further studies which simultaneously estimate bacterial and microflagellate biomass and clearly distinguish between heterotrophic and phototrophic flagellates, it is not possible at this stage to make any more detailed comparisons between carbon flow through oligotrophic and coastal communities.

Estimates of carbon flow through the pelagic microheterotrophic community suggest, therefore, that approximately 20 to $60 \%$ of primary production, possibly representing primarily the dissolved components leaching from discupting phytoplankton cells (Fuhrman and Azam, 1980; Newell et al., 1981) enters the microbial food chain. Much of this is dissipated by the bacteria, only some 5.2 to $8.1 \%$ of the photoassimilated carbon becoming incorporated into bacterial production. At least $66 \%$ of this is exploited by the herotrophic microflagellates leaving a maximum of $34 \%$ of bacterial production for the larger bactivorous suspension feeders.

Acknowledgements. All of the data cited here were collected on joint cruises with either the Department of Sea Fisheries, Cape Town, South Africa, or with the Marine Biological Association, Plymouth, UK. We are grateful to the Director and to Mr. John Henry, both of S.F.R.I., Cape Town, for permission to cite chlorophyll a data from the Nimbus $G$ cruise to the southern Benguela upwelling region, and to Drs. P. J. le B. Williams and P. M. Holligan for permission to cite their unpublished data for primary production from the English Channel. We are additionally grateful to Dr. P. M. Holligan for permission to cite data for biomass of flagellates and ciliates, and for his helpful comments on the manuscript. We also wish to acknowledge receipt of a NERC Postgraduate Fellowship to Ms. E. A. S. Linley and funds from a Royal Society Senior Research Fellowship to R. C. Newell. The use of space and facilities at the NERC Institute for Marine Environmental Research, Plymouth, and the assistance of Ms C. M. Weekley is gratefully acknowledged. 


\section{LITERATURE CITED}

Bowden, W B. (1977). Comparison of two direct count techniques for enumerating aquatic bacteria. Appl environ Microbiol. 33: 1229-1232

Burkill, P. H. (1978). Quantitative aspects of the ecology of marine planktonic ciliated protozoans with special reference to Uronema marinum Dujardin. Ph. D. thesis, University of Southampton

Burkill, P. H. (1982). Ciliates and other microplankton components of a nearshore food-web: standing stocks and production processes. Ann. Inst. Oceanog. 58: 335-350

Collins, K. J., Williams, P. J. Le B. (1977). An automated photochemical method for the determination of dissolved organic carbon in the sea and estuarine waters. Mar. Chem. 5: 123-141

Daley, R. J. (1979). Direct epifluorescence enumeration of native aquatic bacteria: uses, limitations and comparative accuracy. In: Costerton, J. W., Colwell, R. R. (eds.) Native aquatic bacteria: enumeration activity and ecology. Am Soc. for Testing and Materials, Philadelphia, p. 29-45

Delattre, J. M., Delesmont, R., Clabaux, M. Oger, C., Leclerc, H. (1979). Bacterial biomass production and heterotrophic activity of the coastal seawater at Gravelines (France) Oceanol. Acta 2: 317-324

Doetsch, R. N., Cook, T. M. (1973). Introduction to bacteria and their ecobiology. University Park Press, Baltimore

Eppley, R. W., Reid, F. M. H., Strickland, J. D. H. (1970). Estimates of phytoplankton crop size, growth rate and primary production. In: Strickland, J. D. H (ed.) The ecology of the plankton off La Jolla, California, in the period through September 1967. Bull. Scripps Instn Oceanogr 17: $33-42$

Fenchel, T (1980). Suspension feeding in ciliated protozoa: feeding rates and their ecological significance. Microb. Ecol. 6: 13-25

Fenchel, T. (1982a). Ecology of heterotrophic microflagel lates. I. Some important forms and their functional morphology. Mar. Ecol. Prog. Ser. 8: 211-223

Fenchel, T (1982b). Ecology of heterotrophic microflagellates II. Bioenergetics and growth. Mar. Ecol. Prog. Ser. 8: 225-231

Fenchel, T. (1982c). Ecology of heterotrophic microflagellates III. Adaptations to heterogeneous environments. Mar. Ecol. Prog. Ser. 9: 25-33

Fenchel, T (1982d). Ecology of heterotrophic microflagellates IV. Quantitative occurrence and importance as consumers of bacteria. Mar Ecol. Prog. Ser. 9: 35-42

Fenchel, T. (1983). Suspended marine bacteria as food source. In: Fasham, M. (ed.) Proc. NATO Adv. Res. Inst. Bombannes. Plenum Press, in press

Fenchel. T., Jørgensen, B. B. (1977). Detritus food chains of aquatic ecosystems: the role of bacteria. Adv. microb Ecol. 1. 1-49

Ferguson, R. L. (1981). Phytoplankton and bacterioplankton. In: Effect of contaminants on food web dynamics in the Gulf of Mexico. Ann. Prog. Rep., N.M.F.S. Beaufort Lab. North Carolina, USA, p. 51-64

Ferguson, R. L., Palumbo, A. V. (1979). Distribution of suspended bacteria in neritic waters south of Long Island during stratified conditions. Limnol. Oceanogr. 24 (4): $697-705$

Ferguson, R. L., Rublee, P. (1976). Contribution of bacteria to the standing crop of coastal plankton. Limnol. Oceanogr. 21: $141-145$

Fuhrman, J. A. (1981). Influence of method on the apparent size distribution of bacterioplankton cells: epifluores- cence microscopy compared to scanning electron microscopy. Mar. Ecol. Prog. Ser. 5: 103-106

Fuhrman, J. A., Ammerman, J. W. Azam, F. (1980). Bacterioplankton in the coastal euphotic zone: distribution, activity and possible relationships with phytoplankton. Mar. Biol. 60: 201-207

Fuhrman, J. A., Azam, F. (1980). Bacterioplankton secondary production estimates for coastal waters of British Columbia, Antarctica and California. Appl. environ. Microbiol. 39: 1085-1095

Fuhrman, J. A., Azam, F. (1982). Thymidine incorporation as a measure of heterotrophic bacterioplankton production in marine surface waters: evaluation and field results. Mar. Biol. 66: 109-120

Gershey, R. M., Mackinnon, M. D., Moore, R. M., Williams, P. J. Le B. (1979). Comparison of three oxidation methods for the analysis of the dissolved organic carbon in seawater. Mar. Chem. 7: 289-306

Haas, L. W., Webb, K. L. (1979). Nutritional mode of several non-pigmented microflagellates from the York River Estuary, Virginia. J. exp. mar. Biol. Ecol. 39: 125-134

Hagström, $\AA$, Larsson, U., Hörstedt, P., Normark, S. (1979). Frequency of dividing cells, a new approach to the determination of bacterial growth rates in aquatic environments. Appl. environ. Microbiol. 37: 805-812

Hanson, R. B., Wiebe, W. J. (1977). Heterotrophic activity associated with particulate size fractions in a Spartina alterniflora salt marsh estuary, Sapelo Island, Georgia, USA and the continental shelf waters. Mar. Biol. 42: 321-330

Heinbokel, J. F. (1978). Studies on the functional role of tintinnids in the Southern Californian Bight. I. Grazing and growth rates in laboratory cultures. Mar. Biol, 47: $177-189$

Hobbie, J. E., Daley, R. J., Jasper, S. (1977). Use of Nuclepore filters for counting bacteria by fluorescence microscopy. Appl. environ. Microbiol. 33 (5): 1225-1228

Hodson, R. E., Azam, F., Carlucci, A. F., Fuhrman, J. A., Karl, D. M., Holm-Hansen, O. (1981). Microbial uptake of dissolved organic matter in McMurdo Sound, Antarctica. Mar. Biol. 61: 89-94

Hollibaugh, J. T., Carruthers, A. B., Fuhrman, J. A., Azam, F. (1980). Cycling of organic nitrogen in marine plankton communities studies in enclosed water columns. Mar. Biol. 59: 15-21

Holligan, P. M., Harris, R. P., Harbour, D. S., Head, R. N Tranter, P. R. G., Weekley, C. M., Newell, R. C., Linley, E. A. S., Lucas, M. I. (1983). The partitioning of organic carbon in mixed, frontal and stratified waters of the English Channel, in prep.

Holm-Hansen, O., Lorenzen, C. J., Holmes, R. W., Strickland, J. D. H. (1965). Fluorometric determination of chlorophyll. J. Cons. perm. int Explor Mer 30: 3-15

Hoppe, H.-G. (1976). Determination and properties of actively metabolizing heterotrophic bacteria investigated by means of micro-autoradiography. Mar Biol. 36: 291-302

Joint, I. R., Morris, R. J. (1982). The role of bacteria in the turnover of organic matter in the sea. Oceanogr. mar. Biol. A. Rev. 20: 65-118

Karl, D. M. (1980). Cellular nucleotide measurements and applications in microbial ecology. Microb. Rev. 44 (4): 739-796

King, K. R., Hollibaugh, J. T., Azam, F. (1980). Predator-prey interactions between the larvacean Oikopleura dioica and bacterioplankton in enclosed water columns. Mar. Biol. 56: $49-57$

Krambeck, C., Krambeck, H. J., Overbeck, J. (1981). Mic- 
rocomputer-assisted biomass determination of plankton bacteria on scanning electron micrographs. Appl. environ. Microb. 42: 142-149

Larrance, J. D., Kovala, P. E. (1966). Formulas for computing the area, the volume and the plasma volume of a phytoplankton cell. Spec. Rep. (38), U.S. Fisheries and Wildlife Service, U. S. Atomic energy Commission, Ref. M66-41

Linley, E. A. S., Newell, R. C. (1981). Microheterotrophic communities associated with the degradation of kelp debris. Kieler Meeresforsch. 5: 345-355

Linley, E. A. S., Newell, R. C., Bosma, S. A. (1981). Heterotrophic utilisation of mucilage released during fragmentation of kelp (Ecklonia maxima and Laminaria pallida). 1. Development of microbial communities associated with the degradation of kelp mucilage. Mar. Ecol. Prog. Ser. 4: $31-41$

Lorenzen, C. J. (1966). A method for the continuous measurement of in vivo chlorophyll concentration. Deep Sea Res. 13: $223-227$

Lorenzen, C. J. (1967). Vertical distribution of chlorophyll and phaeopigments: Baja, California. Deep Sea Res. 14: $735-746$

Lucas, M. I., Newell, R. C., Velimirov, B. (1981). Heterotrophic utilisation of kelp (Ecklonia maxima and Laminaria pallida). II. Differential utilisation of dissolved organic components from kelp mucilage. Mar. Ecol. Prog. Ser. 4: $43-55$

Meyer-Reil, L.-A. (1977). Bacterial growth rates and biomass production. In: Rheinheimer, G. (ed.) Microbial ecology of a brackish water environment. Springer-Verlag, New York, p. 223-236

Newell, R. C. (1983). The biological role of detritus in the marine environment. Proc. NATO Adv. Res. Inst. Bombannes, May 1982. Plenum Press, New York, in press

Newell, R. C., Linley, E. A. S., Lucas, M. I. (1983). Bacterial production and carbon conversion based on saltmarsh plant debris. Estuar. coast. Shelf Sci., in press

Newell, R. C., Lucas, M. I. (1981). The quantitative significance of dissolved and particulate organic matter released during fragmentation of kelp in coastal waters. Kieler Meeresforsch. 5: 356-369

Newell, R. C., Lucas, M. I., Linley, E. A. S. (1981). Rate of degradation and efficiency of conversion of phytoplankton debris by marine micro-organisms. Mar. Ecol. Prog. Ser. 6: 123-136

Newell, S. Y., Christian, R. R. (1981). Frequency of dividing cells as an estimator of bacterial productivity. Appl. Environ. Microbiol. 42 (1): 23-31

Parsons, T. R., Stephens, K., Strickland, J. D. H. (1961). On the chemical composition of eleven species of marine phytoplankters. J. Fish. Res. Bd Can. 18 (6): 1001-1014

Payne, W. J. (1970). Energy yields and growth of heterotrophs. A. Rev. Microbiol, 24: 17-52

Payne, W. J., Wiebe, W. J. (1978). Growth yield and efficiency in chemosynthetic micro-organisms. A. Rev. Microbiol. 32: $155-183$

Payne, W. J. Williams, M. L. (1976). Carbon assimilation from simple and complex media by prototrophic heterotrophic bacteria. Biotechnol. Bioeng. 18: 1653-1655

Pomeroy, L. R., Johannes, R. E. (1968), Occurrences and respiration of ultraplankton in the upper 500 metres of the ocean. Deep Sea Res. 51: 381-391

Robertson, M. L., Mills, A. L., Zieman, J. C. (1982). Microbial synthesis of detritus-like particles from dissolved organic carbon released by tropical seagrasses. Mar. Ecol. Prog. Ser. 7: 279-285
Ryther, J. H. (1969). Photosynthesis and fish production in the sea. Science, N. Y. 166: 72-76

Sieburth, J. McN. (1979). Sea microbes. Oxford University Press, New York

Sieburth, J. McN., Smetacek, V., Lenz, J. (1978). Pelagic ecosystem structure: heterotrophic compartments of the plankton and their relationship to plankton size fractions. Limnol. Oceanogr. 23: 1256-1263

Sorokin, Y I. (1971a). On the role of bacteria in the productivity of tropical oceanic waters. Int. Revue ges. Hydrobiol. 56: $1-48$

Sorokin, Y. I. (1971b). Bacterial populations as components of oceanic ecosystems. Mar. Biol. 11: 101-105

Sorokin, Y I. (1975). Heterotrophic microplankton as a component of marine ecosystems. J. Obschei. biologii. M. 36: $716-730$

Sorokin, Y. I. (1977). The heterotrophic phase of plankton succession in the Japan Sea. Mar. Biol. 41: 107-117

Sorokin, Y. I. (1978). Decomposition of organic matter and nutrient regeneration. In: Kinne, $O$. (ed.) Marine ecology, Vol. IV, Dynamics. Wiley, Chichester, p. 501-616

Sorokin, Y. I. (1981). Microheterotrophic organisms in marine ecosystems, pp. 293-342. In: Longhurst, A. R. (ed.) Analysis of marine ecosystems. Academic Press, New York, p. $293-342$

Sorokin, Y I., Mikheev, V. N. (1979). On characteristics of the Peruvian upwelling ecosystem. Hydrobiologia 62 (2): 165-189

Spittler, P. (1973). Feeding experiments with tintinnids. Oikos 15 (Suppl.): 128-132

Straškrabová, V., Sorokin, Y I. (1972). Determination of cell size of micro-organisms for the calculation of biomass. In: Sorokin, Y I., Kodota, H. (eds.) I.B.P. Handbook (23). Blackwell, Oxford, p. 48-50

Stuart, V., Newell, R. C., Lucas, M. I. (1982). Conversion of kelp debris and faecal material from the mussel Aulacomya ater by marine micro-organisms. Mar. Ecol. Prog. Ser. 7: 47-57

Troitsky, A. S., Sorokin, Y. I. (1967). On the methods of calculation of the bacterial biomass in water bodies. Trans. Inst. Biol. Inland Waters Acad. Sci. U.S.S.R. 19: 85-90

Van Es, F. B., Meyer-Reil, L.-A. (1982). Biomass and metabolic activity of heterotrophic marine bacteria. In: $M$. Alexander (ed.) Advances in microbial ecology, in press

Watson, S. W., Novitsky, T. J., Quinby, H. L., Valois, F. W. (1977). Determination of bacterial number and biomass in the marine environment. Appl. environ. Microbiol. 33: 940-954

Wiebe, W. J., Pomeroy, L. P. (1972). Micro-organisms and their association with aggregates and detritus in the sea: a microscopic study. Memorie Ist. ital. Idrobiol. 29 (Suppl): 325-352

Wiebe, W. J., Smith, D. F. (1977). Direct measurement of dissolved organic carbon release by phytoplankton and incorporation by microheterotrophs. Mar. Biol. 42: 213-223

Williams, P. J. Le B. (1981). Incorporation of microheterotrophic processes into the classical paradigm of the planktonic food web. Kieler Meeresforsch. 5: 1-28

Zimmermann, R. (1977). Estimation of bacterial numbers and biomass by epifluorescence microscopy and scanning electron microscopy. In: Rheinheimer, G. (ed.) Microbial ecology of a brackish water environment. Springer-Verlag, Berlin, p. 103-120 